The social constructivist approach to the development of technology is adopted to study the development of two ultracentrifuges which have emerged somewhat independently of each other. In a comparative analysis of

these two cases, the socially constructed character of the artefacts is demonstrated: it is shown that the different designs of the two ultracentrifuges reflect the different meanings attributed to them by the researchers involved. Finally, two important aspects are identified which should play a role in theoretical explanations of the developmental process of technological artefacts.

\title{
Two Ultracentrifuges: A Comparative Study of the Social Construction of Artefacts
}

\section{Boelie Elzen}

During the last few years, promising new approaches in the sociology and history of technology have emerged. An important element in these new technology studies is that the analysis of technological artefacts is constituted by a 'seamless web' of economic, political, cultural, technical, natural and social aspects. Hughes, for instance, describes technological innovation and stabilization in terms of a 'systems' metaphor. A system can be understood as a physical network (for example, an electric power distribution system), but in Hughes' vocabulary the word has a broader meaning. The argument is that for those who build artefacts it does not suffice to concern themselves with technology alone: they must also consider social, economic, political and scientific factors. All of those are interrelated and all are potentially malleable. ${ }^{1}$ Callon, Latour, Law and Rip have argued that 'the stability and form of artefacts should be seen as a function of the interaction of heterogeneous elements as these are shaped and assimilated into a network'. ${ }^{2}$ In his study of the Portuguese expansion, Law shows that in the fifteenth century the Portuguese had to conquer technical, natural and social elements in

Social Studies of Science (SAGE, London, Beverly Hills and New Delhi), Vol. 16 (1986), 621-62 
order to find new places and products for trade, and has coined the term 'heterogeneous engineering' for this activity. ${ }^{3}$ Pinch and Bijker have argued that technological artefacts should be understood as social constructs. They have demonstrated that artefacts are designed and developed in a process in which social as well as technical elements play an important role. ${ }^{4}$

A second important element in the new technology studies is that economists and sociologists are starting to study the 'content' of technological artefacts instead of treating artefacts as 'black boxes'. Recently two collections of papers have appeared in which the theme of a sociology of the content of technology is developed. ${ }^{5}$ Pinch and Bijker have shown that the development of the bicycle was influenced not only by technological factors but also by social factors. ${ }^{6}$

Furthermore, some recent technology studies stress the importance of giving a symmetrical treatment of successful and failing artefacts. ${ }^{7}$ If we want to understand technological development, it is argued, we should not use its success as an explanatory category. On the contrary, the success or failure of an artefact needs explanation - it should be considered as the explanandum rather than the explanans. Thus it is important to study the history of failed artefacts as well as the history of successful artefacts.

Some of the new approaches were brought together in a workshop held in the summer of 1984. As one commentator has noted in discussing this workshop, "we may look back to it as the place where the social study of technology first became a recognizable field' ${ }^{8}$ An edited volume of papers from this workshop will appear next year. ${ }^{9}$

\section{The Social Construction of Technology}

In this study I have adopted the 'Social Construction of Technology' approach (known as SCOT). In SCOT, technological artefacts are understood as social constructs. To understand their development Pinch and Bijker suggest that we should identify social groups for which an artefact has some relevance. ${ }^{10}$ The key requirement for belonging to a certain social group is that all members of that group share the same set of meanings, attributed to a specific artefact. The concept 'relevant social group' (RSG), and especially the meaning each group attributes to an artefact, are used to show that it is just not possible to picture an artefact in any straightforward way. Or to put it more radically: the artefact as such does not exist. What exists are the 
various meanings given to an artefact by various social groups. In the case of the bicycle, Pinch and Bijker have shown that for some relevant groups the air tyre was a means to move faster, while others saw an 'ugly looking way of making the low-wheeler yet more unsafe . . . than it already was'. ${ }^{11}$ These authors talk of 'interpretative flexibility'12 to denote the differences in giving meaning to a technological artefact, differences which represent a range of potential lines of development of the artefact, and thus indeed may be said to constitute different 'artefacts'. It is the existence of interpretative flexibility which lead Pinch and Bijker to claim that technological artefacts are 'socially constructed'.

After having identified the relevant social groups for a certain artefact, Pinch and Bijker suggest that we should look for the problems each group has with respect to the artefact. Often, around each problem, several variants of solutions can be identified. Describing the developmental process in terms of problems and solutions will bring out various kinds of conflicts: conflicting technical requirements; conflicting solutions to the same problem; moral conflicts; and so on. ${ }^{13}$ Thus, in the SCOT approach, no a priori distinction is made between the influence of, for instance, technical, natural or social factors.

To follow this approach implies that the developmental process of a technological artefact is described in a 'multi-directional' model. ${ }^{14}$ In many innovation studies a linear model is used to describe the development of an artefact from its invention to production and deployment. To see such a linear development, however, is usually a distortion of hindsight. On closer inspection it often appears that lines of development go in many directions; some of those die out while others survive. 'Promising' lines can still die out, and seemingly 'dead' lines may be revived and become successful after all. Therefure, Pinch and Bijker argue that we should not speak of the 'invention' of an artefact, but that it is more appropriate to speak of growing and diminishing degrees of 'stabilization' ${ }^{15}$ Thus, as noted previously, SCOT treats failed and successful artefacts in a symmetrical way. Moreover, by looking for growing and diminishing degrees of stabilization, the SCOT approach shows that often it is not even possible to use the concepts 'success' and 'failure' in an unambiguous way. In this paper I will show that at some time one specific ultracentrifuge-artefact was considered 'successful', while at a later moment it was 'failing', and another ultracentrifuge was 'successful'.

The objective of SCOT is not only to provide a model for the study 
and description of technological artefacts, but also to explain such developmental processes theoretically. In a forthcoming paper Bijker has developed some categories which could play a role in such theoretical explanations. ${ }^{16}$ Using the same model to carry out more empirical case studies would enable the further development of such a theory.

In this paper, I shall use the SCOT model to describe the development of a technological artefact called an 'ultracentrifuge' (abbreviated as UC). I shall emphasize the social-constructivist character of this development, and show that the question 'what is an ultracentrifuge?' can have varied answers. For different persons the artefact had a different meaning; they tended to regard different aspects of the artefact as problematic, and influenced these in different ways. Consequently, the design of the artefacts reflected the context of their development and the different ways they had been 'problematized'. The result was a set of widely diverging developmental processes and artefacts.

Although the development of a theoretical framework is not my primary objective in this paper, the comparative nature of this case study tempts me to make some reference to theoretical notions. This is because the study shows a number of mutually fairly independent routes of development. Comparison of these routes enables us to trace differences and similarities in the developments. Such a comparative study may help to identify how the meanings attributed by various social groups to an artefact, influence its developmental process and design. As the study will show, one type of ultracentrifuge was eventually produced commercially and widely used, whereas the other type ended up in the Science Museum. In this respect it may seem surprising that it was the latter, developed and used by a Nobel Prize winning scientist, which produced the most widely acclaimed scientific results. In using the same approach for studying both 'failed' and 'successful' developments, I will be able to indicate some factors which are important in explaining increasing or decreasing stabilization of an artefact. Although I will not go into these theoretical questions in detail, I will indicate some aspects which, I think, should play a role in theoretical explanations.

In the following, I shall first describe some technological aspects and applications of ultracentrifuges, and continue with a historical outline of the development of two particular ultracentrifuges. These developments partly overlapped in time (in the 1930s) and took place in two countries (Sweden and the USA), which were comparable in 
general technological level. As I intend to make a comparison between the two case studies, I shall not describe them as two separate histories, but I select three phases in their developments to serve as starting points for my account: 'Early History of Ultracentrifuges', 'Course of Further Developments', and 'Diffusion of Ultracentrifuges'. In the final section I shall summarize the results and indicate some factors which could play a role in theoretical explanations of the development of technological artefacts.

\section{Ultracentrifuges}

In many laboratories and industrial plants there are artefacts called 'ultracentrifuges'. All of these have something called a 'rotor' which rotates at very high speeds (see Figure 1). Since these speeds can lead to considerable air friction which limits the speed of the rotor, this friction is controlled by spinning the rotor in a vacuum, or in a chamber filled with light gas.

FIGURE 1

Schematic Representation of an Ultracentrifuge

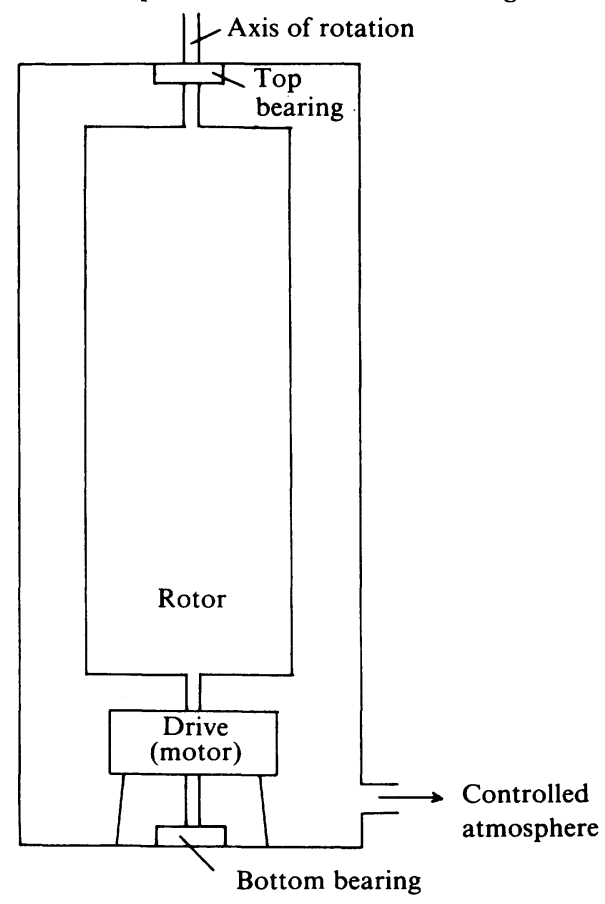


In the 1920s and 1930s, important scientific results were obtained using ultracentrifuges. In 1926, one researcher, the Swedish chemist Theodor Svedberg, was awarded the Nobel Prize for work using ultracentrifuges from 1924 onward. Had Svedberg been asked, in the mid-1930s, to describe an ultracentrifuge, he probably would have described the apparatus shown in Figure 2. Amongst its main characteristics are:

- an oil-turbine drive,

- a carefully balanced oval rotor spinning around a horizontal axis,

- journal bearings with damping arrangements,

- a rotor spinning in a hydrogen atmosphere at reduced pressure, and

- sedimentation in a removable (sedimentation) cell.

\section{FIGURE 2}

Schematic Representation of the Svedberg Ultracentrifuge with an Oil-turbine Drive

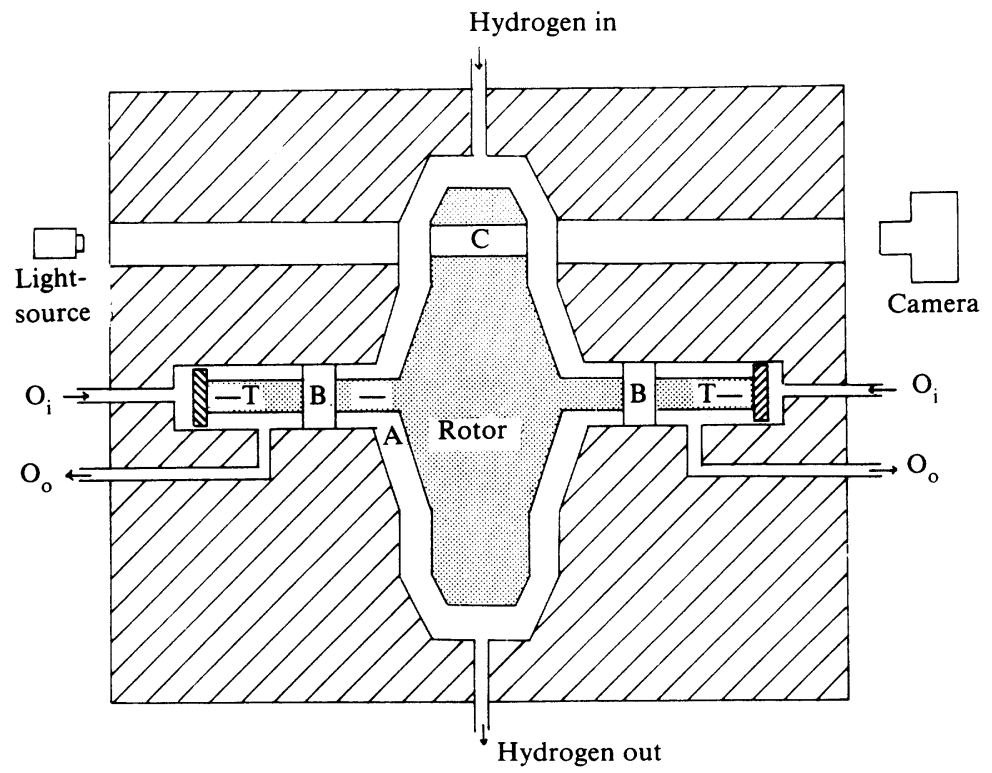

Glossary

$\mathrm{O}_{\mathrm{i}}=$ oil inlet

$\mathrm{O}_{\mathrm{o}}=$ oil outlet

$\mathrm{T}=$ Turbine

$\mathrm{B}=$ (journal) Bearing with damping arrangement

$\mathrm{C}=$ (sedimentation) Cell

$\mathrm{A}=$ Axis of rotation 
Svedberg used this type of ultracentrifuge for scientific experiments in protein and colloid chemistry.

However, had the American researchers Jesse Wakefield Beams and Edward Greydon Pickels been asked to describe an ultracentrifuge in the mid-1930s, they probably would have shown us the apparatus shown in Figure 3. Its main characteristics are:

- an air-turbine drive,

- an oval rotor spinning around a vertical axis,

- bronze or brass oil-glands (the 'bearings'), and

- a rotor spinning in a vacuum.

FIGURE 3

Vacuum Ultracentrifuge Developed by Beams and Pickles

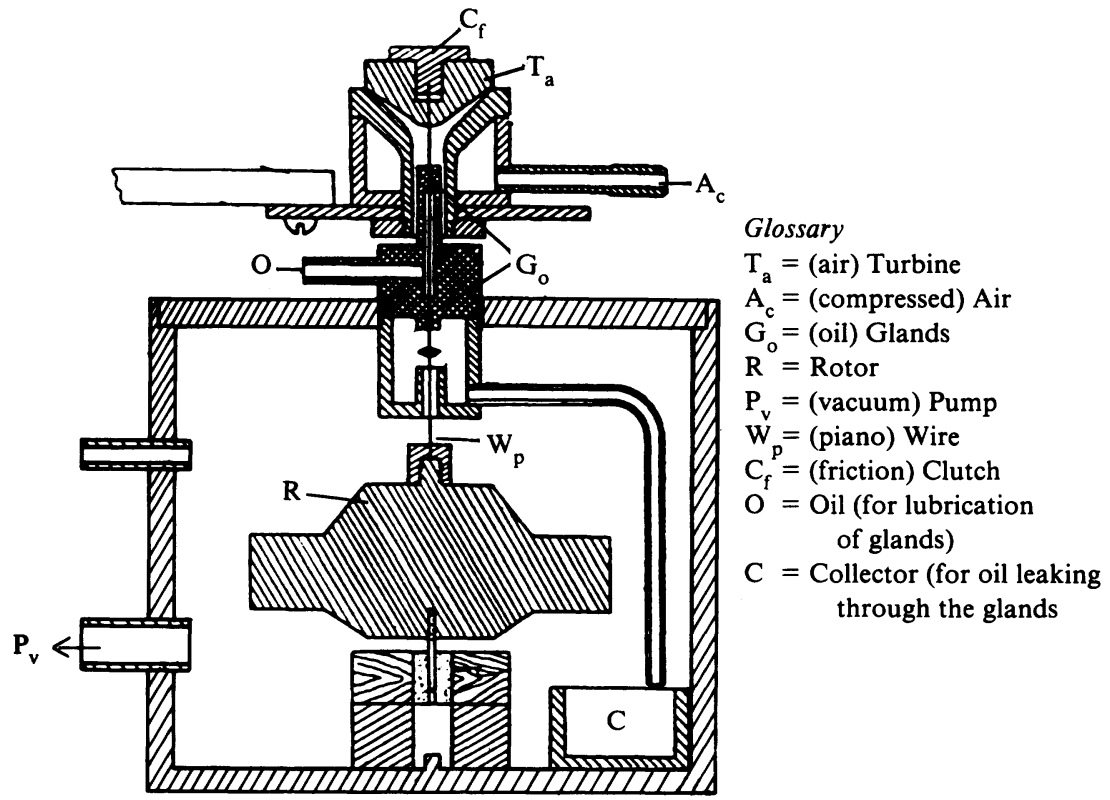

Source: J.W. Beams and E.G. Pickels, 'The Production of High Rotational Speeds', Review of Scientific Instruments, Vol. 6 (1935), 303.

A variety of people used this type of ultracentrifuge for various purposes - for example, for scientific experiments in protein and colloid chemistry.

At that time, then, the question 'What is an ultracentrifuge?', simple though it may seem, would probably have yielded different answers with little in common. ${ }^{17}$ 


\section{Early History of Ultracentrifuges}

\section{Theodor Svedberg: 1904-24}

In January 1904, Theodor (The) Svedberg started to study chemistry, and especially colloid chemistry at Uppsala University (Sweden). ${ }^{18}$ Colloid chemistry is generally regarded as having been founded by Thomas Graham in the 1860s, when he divided all substances known into two classes, depending on their diffusion properties: 'crystalloids' and 'colloids'. Graham studied both free diffusion and diffusion through membranes and found that crystalloids diffuse readily through a membrane and move rapidly in free diffusion, while colloids (derived from the Greek word for 'glue') do not penetrate a membrane such as parchment paper and move extremely slowly in free diffusion. ${ }^{19}$ Graham had formulated a central problem: 'whether the colloid molecule may not be constituted by the grouping together of a number of small crystalloid molecules, and whether the basis of colloidality may not really be this composite character of the molecules'. ${ }^{20} \mathrm{He}$ introduced the names 'sol' for a colloid solution and 'gel' for the product formed by the setting of the solution.

At the turn of the century many of the best known colloids were also known to exist in a form constituted by small particles. In these reversibly dissociable systems the colloidally dispersed phase was considered to be an aggregate of smaller units held together by secondary forces. Many chemists spoke of a 'colloidal state of matter', and a belief developed that any substance, under appropriate conditions, could be converted to a 'colloidal state'. An extension of this view was the converse notion that all colloids were aggregated clusters of molecules. ${ }^{21}$

Arriving at Uppsala, Svedberg plunged straight into the new colloid chemistry. Using the tools of physical chemistry, he tackled the problem of reproducibly preparing stable colloids in order to permit quantitative study of the relation between particle size and other physical properties. He refined Georg Bredig's electric arc technique for the preparation of gold and platinum hydrosols, and he assembled an ultramicroscope following the new design of Zsigmondy and Siedentopf. ${ }^{22}$

In 1903, the German chemist Richard Adolf Zsigmondy, together with $\mathrm{H}$. Siedentopf, an optician with the firm of Zeiss, had developed the ultramicroscope which made it possible to study various aspects of colloidal behaviour directly. ${ }^{23}$ Since then, the ultramicroscope has 
become a powerful instrument in colloid chemistry research. One of the important aspects of colloidal behaviour, as revealed by the ultramicroscope, is that colloids exhibit Brownian movement. In 1905-06, Albert Einstein developed the theory of Brownian movement, which played an important role in assimilating the chemistry of colloids to the general concepts of physical chemistry. By showing that the same principles were applicable to the random thermal motion of small molecules and of much larger, visible particles, he went far to break down the distinction between colloids and crystalloids. $^{24}$

The study of Brownian movement became an important topic in colloid chemistry, and it comprised a major part of Svedberg's dissertation, which was completed in $1907 .{ }^{25} \mathrm{He}$ also studied the effect of particle size upon optical absorption, as well as the coagulation of hydrosols upon the addition of electrolyte, particularly investigating the influence of temperature. Upon completion of his dissertation in 1907, Svedberg and his students continued to work upon these topics, and Uppsala became known as a centre for quantitative work on inorganic sols. Between 1905 and 1912, Svedberg published over 40 papers dealing with various aspects of colloidal behaviour ${ }^{26}$ and, in 1909, he wrote a well received monograph about different methods for preparing colloidal solutions of inorganic substances. ${ }^{27}$

By 1910, Svedberg had become quite a well known and respected experimentalist in his field, but nevertheless his position at the university was insecure. At the time there were only a few permanent academic positions in Sweden, and 'docents' such as Svedberg only held their posts for six or, exceptionally, seven years. In order to keep Svedberg at Uppsala University, in September 1911 two Professors of Chemistry proposed that he be offered a personal chair. This proposal was agreed and on 29 June 1912 Svedberg was appointed to the first Chair of Physical Chemistry in Sweden. ${ }^{28}$

For the next 10 years, research work by Svedberg and his collaborators was devoted mainly to the study of the physicochemical properties of colloidal systems, particularly the size distribution of their particles. These activities resulted in some important general findings which were published in several dissertations by his students: a work on Brownian movement by Westgren in 1913 led to a well founded value for Avogadro's number (a basic unit in chemistry); in 1914, Nordenson described the effect of light on colloidal systems; in 1918 , Nordlund produced a study on mercury 
sols; an investigation into the relationships between light absorption and particle size was published by Pihlblad in 1918, and, in 1921, Börjeson produced a study on the electric synthesis of colloids. ${ }^{29}$

Svedberg can be said to have belonged to the social group of colloid chemists. He shared their research objectives, published in their journals and was to receive a Nobel Prize thus labelled. Typically, colloid chemists studied the behaviour of colloidal systems under various circumstances, and using a variety of experimental methods. The methods and accompanying apparatus were sometimes designed and developed by the scientists themselves, sometimes copied from another scientist in the field and then adapted to their own specific purposes. They often made the apparatus themselves with the help of assistants, or had it made in some shop in town. The primary objective of these scientists was to do scientific research in the field of colloid chemistry. For them, the technological artefacts they used were an aid in solving scientific problems.

In the view of Svedberg, an important problem in colloid chemistry was the determination of the distribution of particle sizes in sols. Until 1910 , such studies had hardly been performed. ${ }^{30}$ Most determinations until then had only resulted in a mean particle size. In 1911, Svedberg pointed out that use of the ultramicroscope would unquestionably allow scientists to obtain the distribution curve for the particles, but the work would be very tedious. Two possible methods were outlined: for coarser colloids and suspensions the rate of sedimentation could be measured; for finer colloids displacement due to the Brownian movement could be measured. If this were done for a sufficiently large number of particles, a distribution curve would be obtained. ${ }^{31}$

These methods were, however, very time-consuming and number of faster methods was also tried. In 1915, one of Svedberg's collaborators developed a method which made use of the fact that the heavier particles in a colloidal solution sink under the influence of gravity more rapidly than the lighter ones. The amount of sediment was measured as a function of time. Subsequently, the theoretical relation between particle size and sinking speed made it possible to determine the distribution of particle sizes. ${ }^{32}$ However, this method was not very accurate when used for small quantities of material. In 1922 , Svedberg found a different way to register sedimentation as a function of time, with a result ten times more accurate than the old method. ${ }^{33}$ Particles with sizes down to approximately $150 \mathrm{~nm}(1 \mathrm{~nm}=$ one millionth of a mm) could now be measured. Though interested in even smaller particles, Svedberg was unable to improve on the 
accuracy of his method. Then it occurred to him that he might achieve his objective, not by trying to improve the recording method, but rather by manipulating one of the 'constants' of his method namely, gravity. Gravity, it is true, is constant on the earth's surface, but with the help of a centrifuge forces can be generated that are many times stronger than those resulting from the earth's gravitational field. ${ }^{34}$

After having defined a scientific problem, Svedberg and his collaborators designed and developed various methods and artefacts to tackle it. The problem of wanting to go down to ever smaller particles first resulted in the manipulation of various technological factors in their experimental method. At a certain point, however, Svedberg started to manipulate a factor which up till then was considered to be a natural constant - gravity. This form of 'heterogeneous engineering' thereupon led to a whole new line of development in which centrifuges were to play a central role.

The use of centrifuges, however, apart from solving one problem, presented others. Thus Svedberg figured it would be virtually impossible to register sedimentation as a function of time. Better results would, he thought, be obtained by determining particle concentration as a function of the height of the column of sediment. ${ }^{35}$ To do this, an optical method would be needed to make external observations without disturbing the sedimentation process. Svedberg developed this method himself and tested it by registering the concentration gradient of a colloidal solution in a beaker. The distribution of particle sizes thus registered turned out to correspond roughly with the distribution found with the 'old' method for measuring the sediment. Svedberg's conclusion was that the optical method produced reliable results. ${ }^{36}$

In 1922, Svedberg's colleagues in Uppsala were not very enthusiastic about his proposed centrifuge method. However, at that period Joseph Howard Mathews invited him to visit the University of Wisconsin to lecture for a period of eight months, and to organize research in colloid chemistry. ${ }^{37}$ There, his ideas about the centrifuge method inspired more enthusiasm, and in collaboration with James Burton Nichols he built his first centrifuge, allowing photographic registration of the sedimentation of colloids. However, since sedimentation was affected in an unpredictable way by collisions of particles against the side-walls of the centrifuge, no simple and exact calculation of the rate of sedimentation (as a function of particle size) was possible. ${ }^{38}$ Yet Svedberg was convinced that this problem of 
convection currents was soluble, and on the boat back to Sweden he drew the first sketches of a new type of centrifuge. Back in Uppsala, he and a colleague, Herman Rinde, developed these ideas.

FIGURE 4

Svedberg Ultracentrifuge with Electrical Motor Drive
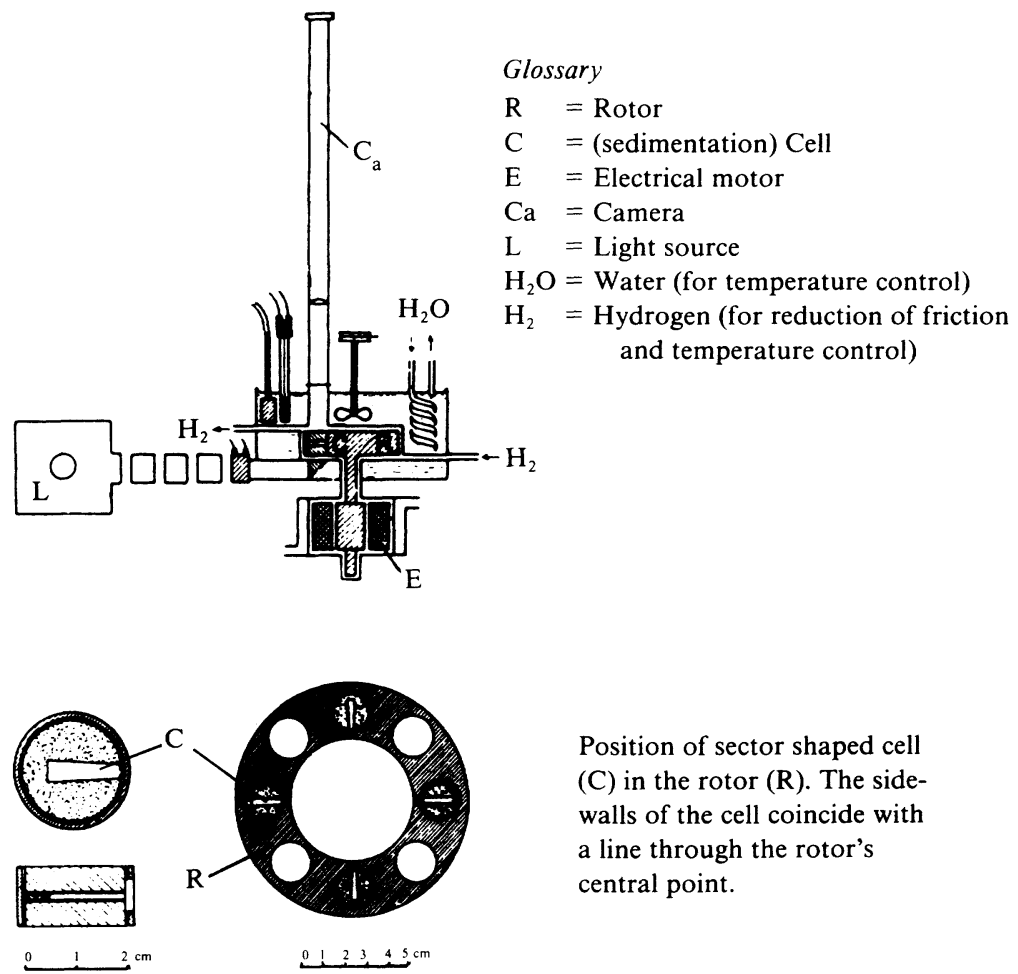

Source: T. Svedberg and K.O. Pedersen (eds), op. cit. note 121, 75 and 80 .

Sedimentation now occurred in a sector-shaped cell (Figure 4; the former cell was tube-shaped). As the gravitational forces generated in the centrifuge were directed from the centre to the periphery, the particles in a sector-shaped cell did not experience forces directed towards the side-walls of the cell. Thus, they expected no more unpredictable movements along the walls of the cell. The cell was placed in a heavy rotor which was fastened to the axis of an existing centrifuge. However, convection currents still occurred. According to the researchers this was either due to vibration in the apparatus, or 
to the heating of the rotor. If the latter were the case, the problem could be solved by making use of the heat-conducting properties of hydrogen. And indeed, when the rotor was spun in a hydrogen atmosphere, convection-free sedimentation was obtained. ${ }^{39}$

At the beginning of 1924, Svedberg and Rinde used the centrifuge to carry out experiments with gold sols. In July of that year, they sent their first article on the subject, in which they stressed the importance of the new apparatus, to the Journal of the American Chemical Society:

... every possible measure should be taken in order to develop this procedure to the point of greatest reliability for the determination of size and distribution of size of particles in very fine-grained sols. ... The new centrifuge constructed by us allows the determination of particles that cannot be made visible in the ultramicroscope. In analogy with the naming of the ultramicroscope and ultrafiltration apparatus, we propose the name ultra-centrifuge for this apparatus. ${ }^{40}$

Figure 4 shows a sketch of this ultracentrifuge. The rotor was driven by a $1.5 \mathrm{hp}$ electrical motor. The connection between rotor and driving shaft showed some play, allowing the rotor to seek its own axis of rotation and thus to be self-balancing, a common technical solution in the centrifuges of that day. The rotational speed was kept at a constant level by the mass of the rotor (weight over $8.5 \mathrm{~kg}$ ) and by some special features for the damping of vibrations. Several precautions ensured that the temperature was also kept at a constant level: when the rotor was spun in hydrogen, there was less heat production than when it was spun in air; in addition, the heat generated in the bearings was conducted away from the rotor more efficiently. Thermocouples, fitted on various locations, allowed the registration of temperature increase during centrifuging. This ultracentrifuge enabled Svedberg to expose colloids to forces of approximately $5,000 \mathrm{gg}^{41}$

To summarize, we may conclude that Svedberg, after his decision to develop the centrifuge method further, started by using generally available technology, in a specific way. Working from the perspective of a colloid chemist, for him the key problem of the centrifuge method was to avoid disturbing sedimentation of the substances under observation. After leading him to the special design of the cells, this perspective focused his attention on the problems of heating and vibration. ${ }^{42}$ The meaning he attributed to the ultracentrifuge, is also reflected in the prefix 'ultra' he adds to the word 'centrifuge': the only thing the three appliances he mentions had in common was 
that they were used in the same scientific field for comparable experiments.

The first application of the ultracentrifuge was for the study of gold sols. The particle sizes registered with the new centrifuge method were compared with the values found with an alternative reliable method. The differences recorded ranged from 10 percent to 40 percent. ${ }^{43}$ In his next article, Svedberg described an experiment showing differences of only a few percent. ${ }^{44}$ In these experiments, sedimentation velocity was recorded by photographing the sedimenting sol at successive intervals of time.

However, problems arose because of diffusion, particularly when smaller particles were being centrifuged for longer periods of time: the colloid particles exhibited Brownian movement, which affected the concentration differences due to sedimentation. ${ }^{45}$ In his experimental method, Svedberg tried to account for the influence of diffusion. This proved to be difficult, since both experimental and theoretical methods for its determination were complicated. ${ }^{46}$ As he put it himself: 'The exact mathematical analysis of this phenomenon has not been worked out . . . but an approximate solution of the problem can be arrived at . . ${ }^{47}$

Shortly thereafter he suggested that it should be possible to account for diffusion in another way - by making use of the fact that after a certain period an equilibrium develops between sedimentation and diffusion. After this equilibrium has formed (which in Svedberg's experiments would often take some days) the particle concentrations at various heights would no longer change. In the case of uniform sols or molecular solutions the particle size or molecular weight could then be determined on the basis of a single photographic recording of this state of equilibrium. ${ }^{48}$ Svedberg worked out this idea into a practicable experimental procedure, and subsequently often made use of this 'sedimentation equilibrium method'.

It is illuminating to view this episode in terms of Law's network approach. In his network, Svedberg had a 'natural' adversary called 'diffusion' that counteracted him. His way of solving this problem was not by fighting, eliminating or reshaping the adversary, but by leaving the adversary intact and reshaping parts of the network in such a way that his one-time adversary turned into an ally.

Svedberg could now use his ultracentrifuge for two different experimental methods - namely, the 'old' sedimentation velocity method and the 'new' sedimentation equilibrium method. For him, the ultracentrifuge had thus gained two different meanings. In terms 
of Pinch and Bijker, at that point there existed two different ultracentrifuges: the 'velocity-UC' and the 'equilibrium-UC'. This interpretative flexibility of the ultracentrifuge could be further demonstrated by spelling out the two distinct sets of problems, respectively linked to the 'velocity-UC' and the 'equilibrium-UC'. As we shall see later on, these two artefacts have indeed followed quite different routes of development, and have resulted in very different machines.

In 1924, Svedberg was the only person in his field with an experimental method suitable for determining the size distribution of very tiny particles (down to sizes of only a few $\mathrm{nm}$ ) in colloids. His first observations showed - surprisingly - that particles were much less uniformly sized than expected. His new method enabled Svedberg to investigate a whole new field of problems concerning the relationship between various physico-chemical properties of colloids and the distribution of their particle sizes.

Jesse Wakefield Beams: 1922-32

In 1925, two Belgian researchers, E. Henriot and E. Huguenard, built an apparatus that was easily capable of very high speeds. The turbine (shown in Figure 5a) consisted of a stator with a cone-shaped recess. The stator was connected to an air compressor which filled the cone-shaped recess with air jets through several channels. When the rotor, also cone-shaped and with flutings, was lowered into the stator the air jets caused it to rotate. In earlier machines, rotating objects had had a solid connection with their driving mechanism. Now, the air jets caused the rotor to hover above the stator on a very thin air cushion, allowing it to seek its own axis of rotation. ${ }^{49}$ In this way, the air-turbine seemed to have overcome problems resulting from critical speeds and imperfect balancing.

With this type of drive Henriot and Huguenard reached rotational speeds of over $660,000 \mathrm{rpm}$ (revolutions per minute), a factor of almost ten more than was possible with other rotating devices at the time. With respect to applications, they indicated that the small rotor might be made hollow in order to separate liquids (Figure $5 b$ ) $^{50}$ or that it might be mounted with a mirror in order to record extremely high speeds at extremely short intervals through observation of a reflected beam of light. This method of measuring was very common in physics; it has served, for instance, as a method for determining the speed of light. 
FIGURE 5

Air Turbine Developed by Henriot and Huguenard (5a) and Rotor

for Separating Liquids (5b)
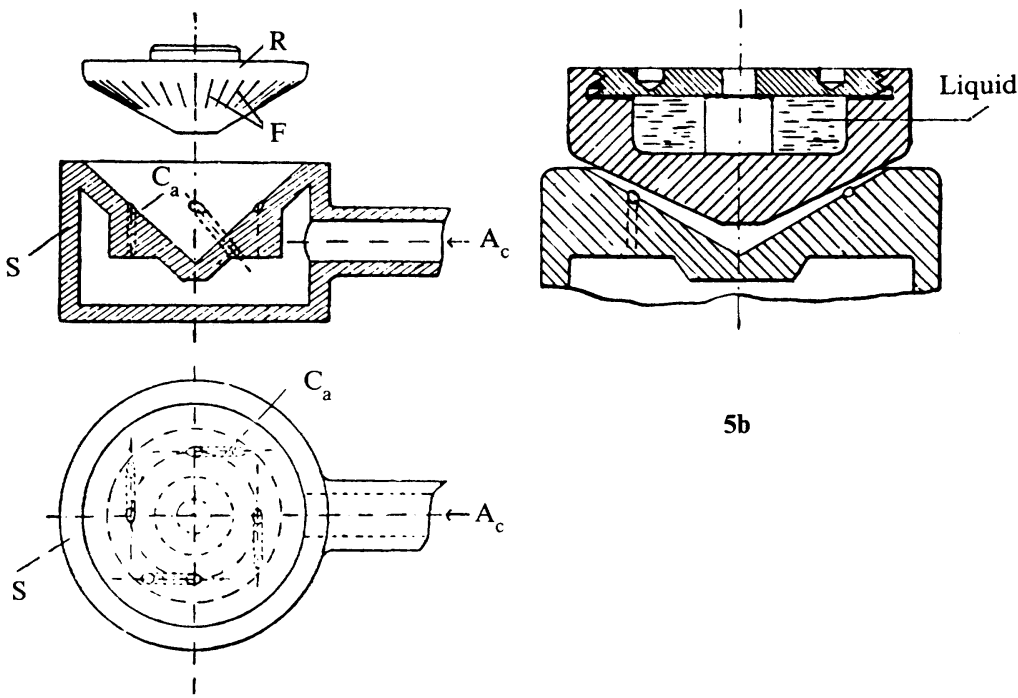

5b

$5 \mathbf{a}$

Glossary

$\mathrm{S}=$ Stator

$\mathrm{R}=$ Rotor

$A_{c}=$ (compressed) Air

$\mathrm{C}_{\mathrm{a}}=$ (air) Channel

$\mathrm{F}=$ Fluttings

Source: Henriot and Huguenard, op. cit. note 50, 436 and 437.

The design of Henriot and Huguenard was picked up by the American physicist Jesse Wakefield Beams. Beams obtained his MA degree in 1922 with a major in Physics. He worked for some time as an instructor in physics at the Alabama Polytechnic Institute (now Auburn University), where he showed great ability as an experimentalist. In 1923-24 he accepted a teaching fellowship at the University of Virginia. There he started research for his $\mathrm{PhD}$, trying 
to measure the time interval between the arrival of the quantum and the ejection of the electron in the photoelectric effect. Although he did not achieve this objective for his thesis, his attempts did lead to the development of experimental techniques and instruments that he and others used for many experiments. With light from a high intensity spark source that was reflected from a mirror rotating at high speed, he produced very short flashes of light for which the onset and duration were measured with a light-switching mechanism which he had developed himself. ${ }^{51}$

Upon receiving his $\mathrm{PhD}$ in 1925 , Beams was awarded a National Research Fellowship, which he held for two years, the first year at Virginia and the second at Yale. Here he collaborated with Ernest $O$. Lawrence on several studies, primarily on experiments concerned with measurement of short time intervals. In many of these experiments they made use of rotating mirrors. ${ }^{52}$ During this work they learned of the work of Henriot and Huguenard and thereupon made a small air turbine for rotating mirrors. Beams and Lawrence found that the rotating mirror was not stable enough for their purposes. In 1928 , they stated that in order to get a 'satisfactory performance' it was necessary to eliminate vibrations in the nozzle from which the compressed air issued. They achieved this goal by means of a rubber mounting for the nozzle. ${ }^{53}$

After his year at Yale, Beams went back to the University of Virginia. Apparently Beams' work was highly valued by the university. When he was offered an attractive job at another university in 1930, the president of the University of Virginia offered to raise Beams' salary and to promote him to a full professorship. ${ }^{54}$ Beams remained at Virginia for the rest of his career.

Using the SCOT model, we could say that Beams belonged to the social group of experimental physicists. Of course, there are obvious differentiations with respect to specific physics areas, but some characteristics are common to nearly all experimental physicists. Pinch found that one is more likely to encounter them on the ground floor or in the basement of the physics department than on the upper floors. They will be working amidst an assortment of instruments and odd pieces of hardware in various stages of assembly, and be surrounded by post-docs, graduate students and technicians. ${ }^{55}$

In the days of Beams and Svedberg, experimenters had to be good machinists and engineers as well, since physics departments seldom had their own machine shop. However, when more funds became available for physics research in the $1920 \mathrm{~s}$, many physics departments 
used part of this money for establishing and improving a machine shop. In the early 1930s, the physics department of the University of Virginia also improved their machine shop, and hired a second machinist. ${ }^{56}$ This made it possible for Beams to continue his technical development work within his physics department. He did not need to turn to 'external' know-how and craftmanship.

In 1930, Beams described an experiment using a rapidly rotating mirror (Figure 6a) to measure the very small time differences in the appearance of spectrum lines in spark discharges. ${ }^{57} \mathrm{He}$ also used the apparatus to study the propagation of luminosity in discharge tubes. ${ }^{58}$ Furthermore, he invested much effort in improving the stabilization and ease of operation of the apparatus, and in 1930 published an article entirely devoted to this. ${ }^{59}$

From this time on, Beams' attention gradually shifted from experimenting with the apparatus to the actual development of centrifuges. In 1931, he published an article in Science entitled: 'A Simple Ultra-Centrifuge'. In the introduction he stated:

It is hardly necessary to emphasize the value of the centrifuge to science in general. Its numerous uses in so many fields of experimental investigation have made it almost a necessary laboratory tool. As a consequence of this wide usage considerable energy has been directed toward the development of centrifuges with our modern high speed machines as a result. ${ }^{60}$

Beams' apparatus was the 'spinning top' artefact, which offered a platform on which little objects such as mirrors could be given high rotational speeds. His scientific interests determined the direction in which he tried to develop the spinning top, for example by improving stabilization. At a certain point, however, the apparatus took on another meaning for him. He started seeing it as a centrifuge, an artefact to create large (centrifugal) forces on objects or substances placed in it. From being a spinning top in physical experiments, it became a centrifuge that could be used in 'science in general'. Again, this interpretative flexibility of Beams' apparatus can be further demonstrated by sketching the two different lines of development which these 'artefacts' followed - each with its own set of typical design problems and solutions, as we shall see later on.

Beams adapted the air-turbine to serve as a centrifuge by making the rotors hollow (Figure $6 \mathrm{~b}$ ). He developed several centrifuges, which differed in the way the centrifuged material was extracted from the rotor while rotating at its maximum speed. The rotor in Figure $6 \mathrm{~b}$ was first filled with material, and then started. After a while, the 
FIGURE 6a

Air Turbine with Mirror Developed by Beams

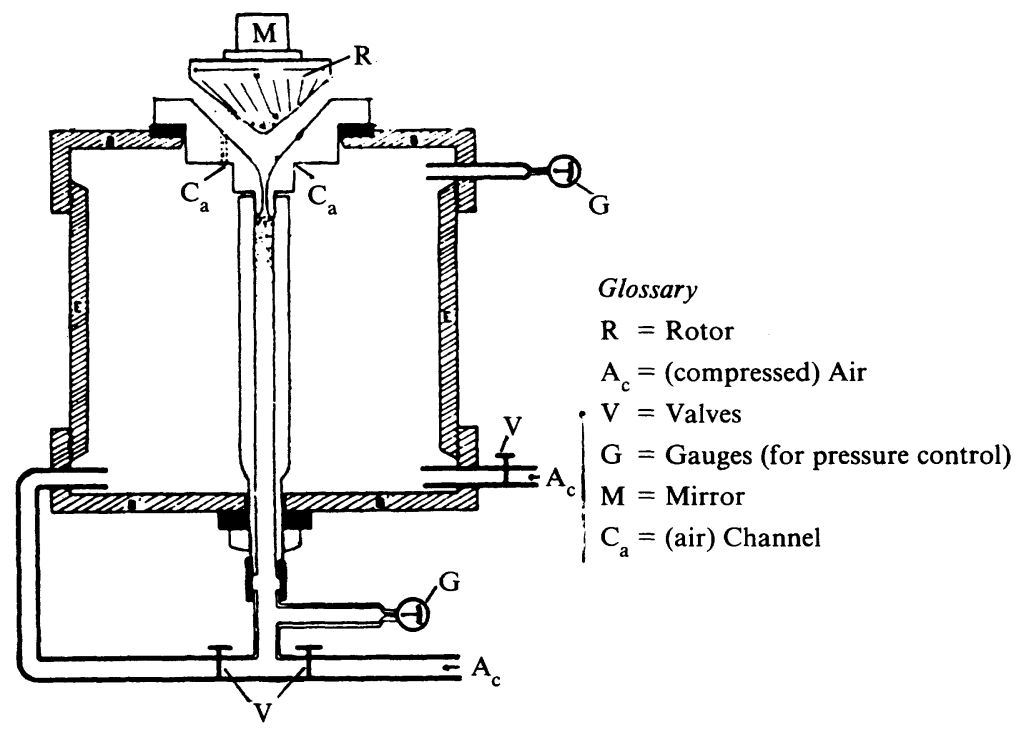

Source: Beams, op. cit. note 59, 668.

FIGURE 6b

Beams' Rotor for Separating Liquids

Source: Beams \& Weed, op. cit. note 60,45 .

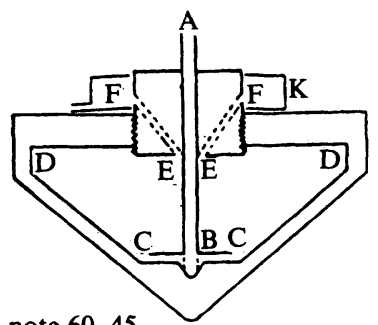

heavier components moved to the periphery (D) and the lighter components were found closer to the rotor's centre. Then a somewhat heavier substance was gradually introduced into the rotor through tube $\mathrm{AB}$, forcing the lighter fraction in the centre into chamber $\mathrm{K}$ through tube EF. After the rotor had been stopped, both separated fractions were tapped. ${ }^{61}$ Yet, in Beams' view, much remained to be improved: rotational speed, bearings, strength of materials, vibrations and methods for making the centrifuging continuous. ${ }^{62}$ 
Like Svedberg, Beams called his apparatus an 'ultracentrifuge'. The only thing the two machines had in common, it seems, is that 'something' rotated very rapidly. One of the main differences between the two was that Svedberg's ultracentrifuge was used for a very specific set of problems, whereas Beams' rotors were developed for a wide range of different applications. One could also say that Svedberg had a specific problem and was looking for a solution to that problem, whereas Beams developed a variety of solutions and afterwards looked for problems that fitted his solutions. The Beams approach implied that there was hardly any limit to the further development of artefacts. In the Svedberg case, as soon as the artefact had solved his original problem, further development of ultracentrifuges could stop. This was the case by the end of 1924. Soon thereafter, however, his scientific results were to get Svedberg into trouble again.

\section{Course of Further Developments}

Svedberg: $1924-37$

By the end of 1924, the ultracentrifuge made it possible for Svedberg to study the distribution of sizes of a variety of colloidal substances. He was interested in studying the usual inorganic colloids, as well as organic substances like proteins. A monograph by F.N. Schulz, published in 1903, portrays the problem of the molecular weight of proteins as it appeared at the turn of the century. ${ }^{63}$ The general situation was confused and uncertain because the methods of physical chemistry used for studying proteins were considered inadequate and unreliable. As Schulz summarized: 'Im Ganzen ist das Bild ein wenig erfreuliches' ${ }^{64}$ Molecular weight data discussed in Schulz's monograph came from a variety of sources: there was the method of so-called 'freezing point depression' which gave a definite, though unreliable, figure for the molecular weight; or a method where a minimum molecular weight was calculated from the total sulphur, iron, cystine or tyrasine content. About this time the first studies of the osmotic pressure of protein solutions began, which, for example, led to a molecular weight near 48,000 for dog haemoglobin (a protein found in blood), three times greater than that calculated from an empirical formula for haemoglobin. ${ }^{65}$ For a variety of reasons, none of the figures obtained were widely acknowledged: 
because of inaccuracy of the experiments; because many experiments proved to be irreproducible; and because of the idea, prevailing in chemistry at the time, that such large molecules simply did not exist. Before the work of Hermann Staudinger, who introduced the concept of macromolecule in 1924, nearly all organic chemists were very reluctant to think of large molecules as true chemical entities, and seriously to consider their possible existence. ${ }^{66}$ Furthermore, most colloid chemists held that 'solutions' of colloids (and thus of proteins, because proteins were considered to be colloids as well) actually were 'suspensions' and, therefore, that the physical-chemical laws of solutions were essentially inapplicable to them. ${ }^{67}$

As noted previously, the theory of Brownian movement as developed by Einstein in 1905-06 did much to break down the distinction between colloids and crystalloids, and indirectly gave encouragement to those investigators who were attempting to describe the behaviour of proteins in terms of the general laws of physical chemistry. ${ }^{68}$ In 1917 , following this line of thought, S.P.L. Sørensen argued that ovalbumin in aqueous salt should be thought of as a true solution because it obeyed a general law of physical chemistry. ${ }^{69}$ Indispensable to this work was the definition of the $\mathrm{pH}$-scale (a measure for the acidity of solutions), and the development of a means of measuring it, which Sørensen himself had worked out some years before. Solubility studies on proteins could not be made reproducible until the necessity of specifying the $\mathrm{pH}$, as well as the salt concentration and temperature, was fully appreciated. Sørensen's work was published during World War I, and it took several years before it became more widely known. The conclusions Sørensen drew, however, were not easily accepted by many of the colloid chemists $^{70}$, and when Svedberg started studying proteins in the mid1920 s, the general idea was that proteins were aggregates of smaller molecules, and that molecules with a mass over approximately 5,000 did not exist.

Svedberg performed the first ultracentrifugal studies of proteins in collaboration with the pathologist Robin Fåhraeus. They started with casein, a milk protein, in which a wide range of particle sizes was distinguished (10 to $70 \mathrm{~nm}) .^{71}$ This was just what Svedberg had expected of a protein. After these first successful experiments Fåhraeus asked Svedberg: 'Why not try to centrifuge a solution of haemoglobin?' Svedberg replied: 'Haemoglobin should only have a molecular weight of about 17,000 according to its iron content, and egg albumin with the double molecular weight did not sediment in the 
ultracentrifuge.' To which Fåhraeus responded: 'I see, but one could in any case try'. ${ }^{72}$

So they did. They started to prepare $\mathrm{CO}$ haemoglobin from horse blood. As soon as the preparation was ready, late in the evening of 16 October 1924, the experiment was started. As Svedberg did not expect to observe anything before the next day, he went home and let Fåhraeus watch the centrifuge. In the middle of the night, Svedberg was woken by a telephone call from Fåhraeus saying: 'The, I see a dawn'. ${ }^{73}$ Svedberg rushed to the Institute, where he found that the upper part of the cell was indeed clearing up, and was separated from the rest by a sharp boundary. This was remarkable, since in earlier experiments, sedimentation became visible as a gradually increasing or decreasing colour intensity, caused by particles with different molecular masses settling at different speeds. Now all particles seemed to be settling at the same speed, which indicated that they might all be the same size. This suggested that haemoglobin was, perhaps, a 'well-defined' molecule, with a molecular mass of $66,800 .^{74}$ However, this possible conclusion was completely contrary to Svedberg's expectations. As he wrote himself a few years later:

When the author, after some series of measurements carried out in cooperation with J.B. Nichols . . . and H. Rinde . . . on inorganic colloids, in particular on goldhydrosols, set the task of studying the dispersity of proteins, he was fully convinced that these, like the gold hydrosols, would prove to be polydisperse. $\mathrm{He}$ therefore set himself the task of determining the distribution curves of protein particle sizes under various experimental conditions. ${ }^{75}$

When Svedberg and Fåhraeus published their experiments in February 1926, they referred to 'preliminary measurements', ${ }^{76}$ and in a footnote they wrote that:

These experiments should be regarded more as an illustration of the method than as a precise determination of the molecular weight of haemoglobin. A more refined technique of measurement will, we hope, enable us to communicate such determinations later on. ${ }^{77}$

The scientist Svedberg was reluctant to make a strong claim of a result that ran counter to his own expectations, and to the beliefs of the majority of other scientists in the field. But the result of the experiment did create a problem - a scientific problem. To help him solve his problem, the ultracentrifuge and/or parts of the network had to change. In order to be able to test whether all haemoglobin particles indeed had the same size, Svedberg saw only one way. This 
was to develop another ultracentrifuge, but with a gravitational field of 70,000 to $100,000 \mathrm{~g}-15$ to 20 times more powerful than his first one. ${ }^{78}$ However, he saw no way to increase the speed of his ultracentrifuge to that extent.

Svedberg's network was in serious danger of crumbling. Simple technological adaptations did not seem able to help him out. But luckily for the heterogeneous engineer, there are other ways of restoring the network into an enduring whole. He could try to have others solve the problem for him. However, before any detailed planning and construction of a new centrifuge could be started, Svedberg had to find the necessary money for financing the project. Money for research was then very scarce in Sweden, and it was almost impossible to finance such a comparatively big project. Fåhraeus advised him to send an application to a new private foundation for medical research. Svedberg applied for 25,000 Swedish crowns, a huge sum at that time. In spite of much opposition he got this grant, and another from the chemistry section of the Nobel Foundation. ${ }^{79}$ According to Svedberg's own interpretation, it was the suggestion that haemoglobin could be monodisperse which stimulated the interest of the new Foundation. ${ }^{80}$

Having been financed, Svedberg contacted Fredrik Ljungström of the Ljungström Steam Turbine Company in Stockholm. Ljungström suggested the use of oil-turbines to drive the centrifuge, thus simplifying lubrication of the bearings. He arranged for one of his younger engineers, Alf Lysholm, to collaborate with Svedberg to build and test an ultracentrifuge in the workshop of the Ljungström Company. ${ }^{81}$ In approaching that Company, Svedberg introduced a particular company 'tradition' in the construction of turbines and rotating systems. This tradition can also be traced in the centrifuges they built for him. Some significant elements of that tradition were the use of a horizontal axis and strong bearings to support the weight of the rotor. Because of the stiffness of the rotor, the bearings also had to damp out vibrations caused by imperfect balancing of the rotor. During rotation at the high speeds required for Svedberg's purposes, these bearings became very hot, and in time the sedimentation cell also heated up. This resulted in inconvenient convection currents. However, in the tradition in question, the stiffness of the rotor and its imperfect balance implied that the bearings would heat up at high speeds. The solution to this problem was therefore to be found in screening off and conducting away the heat. Because the new rotor spun much faster than the old, the hydrogen atmosphere, meant for 
conducting the heat, itself caused the rotor to heat up. If a vacuum were used, however, the heat produced by the bearings could not get away. Ultimately, a solution was found by reducing the pressure of the hydrogen atmosphere, which minimized the heating of the sedimentation cell to an acceptable level. In January 1926, the new ultracentrifuge was tested for the first time in Svedberg's laboratory. It turned out to be only half as fast as was intended. Lowering the pressure of the hydrogen atmosphere increased the speed by 10 to 15 percent. Then the turbines, turbine chambers and oil-system were changed and the bearings were replaced by a new type in order to improve lubrication. On 7 April 1926, the original objective of over $40,000 \mathrm{rpm}$ was attained, generating a force over $100,000 \mathrm{~g} \cdot{ }^{82}$

In September 1926, Svedberg, now collaborating again with Nichols, returned to the question of uniformity in protein molecules. Experimenting with the new centrifuge, they again found no indication of the existence of differently sized particles. ${ }^{83}$

As the Nobel Prize awards show, in the early 1920s colloid chemistry was considered to be a very important field of scientific investigation. In 1921, the Nobel Prize in Physics was awarded to Einstein for 'his services to Theoretical Physics', one of which was his development of the theory of 'Brownian Movement' ${ }^{84}$ At the presentation of the prize to Einstein, the Chairman of the Nobel Committee for Physics stated that colloid chemistry had grown into 'a large branch of science' and he explicitly mentioned the work of Svedberg, Perrin and Zsigmondy. ${ }^{85}$ The 1926 Nobel Prize in Chemistry was awarded to Svedberg for his work on 'disperse systems'. ${ }^{86}$ The 1926 Nobel Prize in Physics was awarded to Jean Perrin for work in the same field, ${ }^{87}$ whereas the postponed 1925 Nobel Prize in Chemistry went to Zsigmondy, also for work on colloids. $^{88}$

The Nobel Prize was not awarded to Svedberg for his work with the ultracentrifuge. It was awarded to him for his many contributions to colloid chemistry, of which his experimental confirmation of Einstein's theory of Brownian movement is mentioned explicitly. ${ }^{89}$ There had, however, been some controversy over his award which led Svedberg to have ambiguous feelings about it. He set himself the goal of using the next ten years to prove that he was really worthy of the Prize. ${ }^{90}$ The Nobel Prize itself turned out to be an important aid in helping him to do so.

In his Nobel Lecture, Svedberg did not talk about the work for which he had been awarded the prize. He only discussed his recent 
work with the ultracentrifuge, especially with the oil-turbine type which he had only been using since a few months before. ${ }^{91}$ In this speech he claimed, for the first time in public, that he had proved haemoglobin to have a definite molecular weight. The Nobel Prize gave Svedberg an extra status which greatly assisted him in obtaining funds for further investigations. For some years Svedberg had been trying to find money for a larger laboratory because his experimental equipment, especially the ultracentrifuges, used ever more space. Some of the apparatus was housed in a former toilet. In the beginning, chances for getting the money seemed to be rather slim. But soon after his Nobel Prize award, the Swedish government financially supported the construction of a new research laboratory for physical chemistry at Uppsala University, allowing Svedberg to design an entirely new ultracentrifuge laboratory, which opened in 1931. Newspaper headings like 'Nobel Prize Winner Works in a Toilet' may have helped. ${ }^{92}$

After the first surprising results with haemoglobin, Svedberg used his ultracentrifuge mainly to study a wide range of proteins. Here, however, the ultracentrifuge still presented him with many problems. In the early years, all measurements in the rotating cell were based upon light absorption. But some substances he wanted to investigate did not have sufficient light absorption. Thereupon, Ole Lamm, one of Svedberg's students, worked out a practicable method based on light deflection. ${ }^{93}$ Furthermore, the desire to investigate ever smaller particles required the use of the highest gravitational forces possible. Therefore one of Svedberg's main objectives in further developing the ultracentrifuge was to increase the gravitational field it generated. To this end, many modifications were tested: the shape and diameter of the rotor, the type of steel, the method of balancing, the turbine shape, bearings, lubrication, and so on. ${ }^{94}$ Thus much detailed technological development work was carried out on the ultracentrifuge.

In the early 1920s, chemical university laboratories in Sweden rarely had mechanical workshops, nor mechanically skilled personnel. Usually, even small construction work had to be sent out to workshops in the city. In the early days of the ultracentrifuge, Ivar Eriksson, who held a position at the workshop of a bicycle factory at Uppsala, used to help Svedberg in his spare time. In developing the ultracentrifuge, however, Svedberg found it necessary to have easier access to mechanical services. Therefore, in 1924, he hired Eriksson to work full-time on the ultracentrifuge and to set up a workshop 
related to the laboratory. ${ }^{95}$ After the first oil-turbine ultracentrifuge had been made at the Ljungström Steam Turbine Company all further changes were made in Eriksson's workshop. ${ }^{96}$ Although in the following decade a lot of modifications were tried, the basic concept of the ultracentrifuge remained unchanged. The results of some of the improvements are shown in Table 1.

TABLE 1

Different Ultracentrifuges Developed Successively by

Svedberg, and the Resulting Centrifugal Field

\begin{tabular}{|c|c|c|}
\hline Year & $\begin{array}{l}\text { Centrifugal } \\
\text { Field }\end{array}$ & $\begin{array}{c}\text { Remarks; Important Characteristics and } \\
\text { Modifications }\end{array}$ \\
\hline 1923 & $500 \mathrm{~g}$ & $\begin{array}{l}\text { Svedberg/Nichols; tube-shaped rotor and cell, } \\
\text { electrical motor. }\end{array}$ \\
\hline 1924 & $5,000 \mathrm{~g}$ & $\begin{array}{l}\text { Svedberg/Rinde; cylindric rotor, sector-shaped cell, } \\
\text { hydrogen-atmosphere. }\end{array}$ \\
\hline 1926 & $100,000 \mathrm{~g}$ & $\begin{array}{l}\text { oil-turbine drive, hydrogen-atmosphere at low } \\
\text { pressure. }\end{array}$ \\
\hline 1931 & $200,000 \mathrm{~g}$ & new type of driving-oil. \\
\hline 1932 & $300,000 \mathrm{~g}$ & oval rotor. \\
\hline 1933 & $400,000 \mathrm{~g}$ & new type of steel. \\
\hline 1935 & $500,000 \mathrm{~g}$ & cell diameter reduced from 30 to $20 \mathrm{~mm}$. \\
\hline
\end{tabular}

In 1935 , Svedberg generated $700,000 \mathrm{~g}$ with a rotor of $10 \mathrm{~cm}$ in diameter (earlier rotors were $18 \mathrm{~cm}$ in diameter). But since the cells of this rotor were necessarily small ( $14 \mathrm{~mm}$ in diameter), the rotor had a resolving power inferior to those with a diameter of $18 \mathrm{~cm}$, and Svedberg turned away from the smaller rotors. ${ }^{97}$ Although increasing the gravitational field was one of Svedberg's aims, it was not an ultimate goal in itself, but a means for doing protein research. When improvements seemed to impair its utility as an experimental tool, this ultracentrifuge lost its appeal for him. In 1937, Svedberg concluded that he had developed his centrifuge to the limits of technical feasibility. ${ }^{98}$

Beams: 1933-42

As mentioned before, experimental physicists like Beams were usually surrounded by graduate students and technicians. One of Beams' students, Edward Greydon Pickels, chose as a topic for his 
doctoral dissertation to develop the spinning top further, to the point that it could be used for sedimentation experiments. ${ }^{99}$ Referring to the work of Svedberg, ${ }^{100}$ Beams and Pickels developed several rotors which would allow the observation of the sedimentation process during centrifuging. The rotor of Figure $7 \mathrm{a}$ had a glass lid that turned out to be too weak to survive the first experiments. Its strength was considerably increased by a special heat-treatment, and the limit became $250,000 \mathrm{~g}$. However, the rotor itself was capable of as much as 400,000 g. ${ }^{101}$

FIGURE 7

Beams' Rotors for Sedimentation Experiments

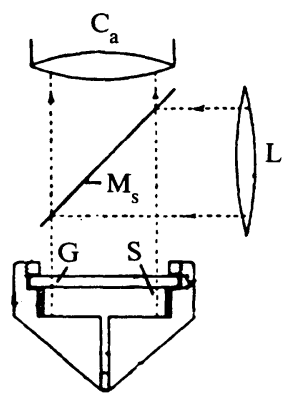

$7 \mathbf{a}$

Glossary

$\mathrm{S}=$ Sedimentation chamber

$\mathrm{G}=$ Glass disk

$\mathrm{L}=$ Light source

$\mathrm{C}_{\mathrm{a}}=$ Camera

$\mathrm{M}_{\mathrm{s}}=$ semi-permeable mirror

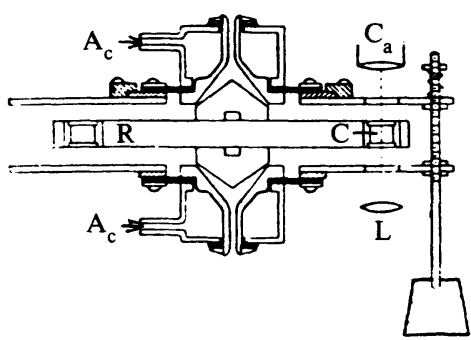

$7 \mathbf{b}$

Glossary

$\mathbf{R}=$ Rotor

$\mathrm{C}=$ (sedimentation) Cell

$A_{c}=$ (compressed) Air

$\mathrm{L}=$ Light source

$\mathrm{C}_{\mathrm{a}}=$ Camera

Source: Beams, Weed \& Pickels, op. cit. note 100, 339.

Another type of rotor suitable for sedimentation observation is shown in Figure 7b. As in the Svedberg ultracentrifuge, this rotor had separate cells in which sedimentation might be observed. It was driven by two turbines in order to increase the maximum speed. With a rotor of $9 \mathrm{~cm}$ in diameter, $100,000 \mathrm{~g}$ was generated, the capacity of the air compressor being the limiting factor. Much care was invested in improving the construction of the cells so that they too might withstand $100,000 \mathrm{~g}$. Despite the limitations of these rotors, Beams and his collaborators were concerned to underline the advantages of their ultracentrifuge: 
First, it is simple and easy to construct; second, the design may be widely varied to suit the need of the experimenter, and still remain extremely stable; third, the cost is very little if air pressure is already available; fourth, the centrifugal forces developed are as high as any materials (as yet tried) of the rotor will safely stand. ${ }^{102}$

The Beams centrifuges were also adopted by other scientists. One of them, E. Newton Harvey, a physiologist, was interested in studying live cells during centrifuging. In 1930, he used a self-made centrifuge to study cells exposed to forces of $2,000 \mathrm{~g}$ under a microscope. ${ }^{103}$ Having appropriately adapted the Beams centrifuge, with the help of Beams himself, he was able to achieve $200,000 \mathrm{~g} .{ }^{104} \mathrm{~A}$ brother of Jesse Beams, Harold W. Beams, from the Zoology Department of the State University of Iowa, also used the centrifuges developed by J.W. Beams to experiment with live cells, but his main interest was in the way cells recover after being centrifuged. ${ }^{105}$ In 1935, J.W. Beams and Pickels wrote that their centrifuges had widespread applicability:

The ... airdriven rotors ... have been utilized already in quite a number of different experiments. It seems to be the best method known for spinning small mirrors at very high speeds. Also it proves to be of considerable value as a centrifuge in biological experiments as is evidenced by the work of Harvey, H.W. Beams and others. Optical schemes have been devised for viewing the biological material while it is being centrifuged. A few successful experiments upon the sedimentation of small particles and molecules from solution have been carried out. ${ }^{106}$

In their view, rotor heating caused by friction was now the main defect of their ultracentrifuge. Another problem that turned up during systematic examination of the relation between air pressure and rotational speed was that, with high speeds and large rotors, rapidly increasing friction losses limited the speed of the rotor. In search of a solution to these problems, Beams and Pickels mentioned Svedberg's work:

... in many experiments for obtaining the rate of molecular sedimentation, the air-driven rotor, surrounded by air at atmospheric pressure, is less satisfactory than the very beautiful but more expensive method of Svedberg. ${ }^{107}$

Yet whereas Svedberg's rotor spun in hydrogen at low pressure, the Beams-Pickels rotor spun in a vacuum. In 1935, they described the vacuum centrifuge in Physical Review, ${ }^{108}$ Science ${ }^{109}$ and Review of Scientific Instruments. ${ }^{110}$

Because Beams saw his ultracentrifuge as an apparatus for general scientific applications, there was hardly any limit on possible further routes of development. Every possible improvement was worth a try 
and, if successful, worth a publication. The meaning he attributed to ultracentrifuges implied that Beams was anxious to have other scientists using his artefacts. So he had to reach as many scientists as possible and try to convince them that his artefacts were of interest to them. He tried to meet the first requirement by publishing his results in journals like Science and Review of Scientific Instruments, which had a readership of varied scientific backgrounds, and in Physical Review, which covered almost the full domain of physics. The second requirement, to convince other scientists, Beams tried to meet by arguing that his artefacts could be easily made, were cheap, could be adapted easily, and so on. When other scientists were convinced in principle, but still saw some problems relating to their specific application, Beams was prepared to try to help them.

Looking for possible applications, Beams had also learned, as we have seen, about the work of Svedberg, and asked Pickels to try and adapt the spinning top for sedimentation experiments. However, their tradition of working - doing everything in their own machineshop - and the meaning they attributed to ultracentrifuges - a widely usable instrument - implied that anything they made should be quite simple to construct. So, when they finally claimed to have reached their goal, it was necessarily with an artefact that was less complicated than Svedberg's (which used the most advanced technology available at the time). True enough, after some years Svedberg also had established his own workshop, but the concept of the oil-turbine ultracentrifuge as a high-tech machine was developed elsewhere.

The main characteristics of the Beams-Pickels vacuum centrifuge are shown in Figure 3. The air-turbine only served as a driving mechanism. The actual rotor was placed in a vacuum chamber and connected to the turbine by means of a steel (piano) wire and a clutch. The clutch prevented the wire from twisting or breaking during sudden acceleration or deceleration. It rotated in two bronze or brass plugs (the 'bearings'), with holes a fraction of a millimeter larger than the diameter of the wire. These bearings (or oil-glands) were continuously lubricated with oil of high viscosity, which at the same time sealed the vacuum chamber. Oil leaking through the bearings (approximately $1 \mathrm{cc}$ an hour) dripped into a special oil-collector.

It was evident from the first experiments that this rotor turned remarkably smoothly. Careful balancing of the rotor appeared unnecessary; even in a rotor of $7.5 \mathrm{~cm}$ in diameter, deliberately unbalanced by a hole of $6 \mathrm{~mm}$ bored near its periphery, no noticeable 
irregularities occurred during spinning. A turbine weighing only 50 grammes would drive an 800 -gramme rotor at a speed only slightly less than that achieved by the turbine alone. The maximum rotational speed was limited only by the strength of the materials used in the rotor. A duralumin rotor with a diameter of $8 \mathrm{~cm}$ exploded at 132,000 rpm, corresponding to a gravitational field of $900,000 \mathrm{~g} .{ }^{111}$

But a Svedberg-type application was just one of the many possible applications Beams saw for his artefacts. In 1935, he wrote:

No attempts will be made here to make a detailed list of the numerous uses of the apparatus described in this article for obtaining high rotational speed in vacuum. The fact that rotors of a wide range of sizes, shapes and weight can be spun smoothly in a really good vacuum obviously adds greatly to their utility. Also the only parts to wear out are the bearings which may be made replaceable. ${ }^{112}$

Photo 1 gives an impression of the range of rotors Beams developed for the vacuum centrifuge.

\section{PHOTO 1}

Rotors Developed by Beams for the Vacuum Centrifuges

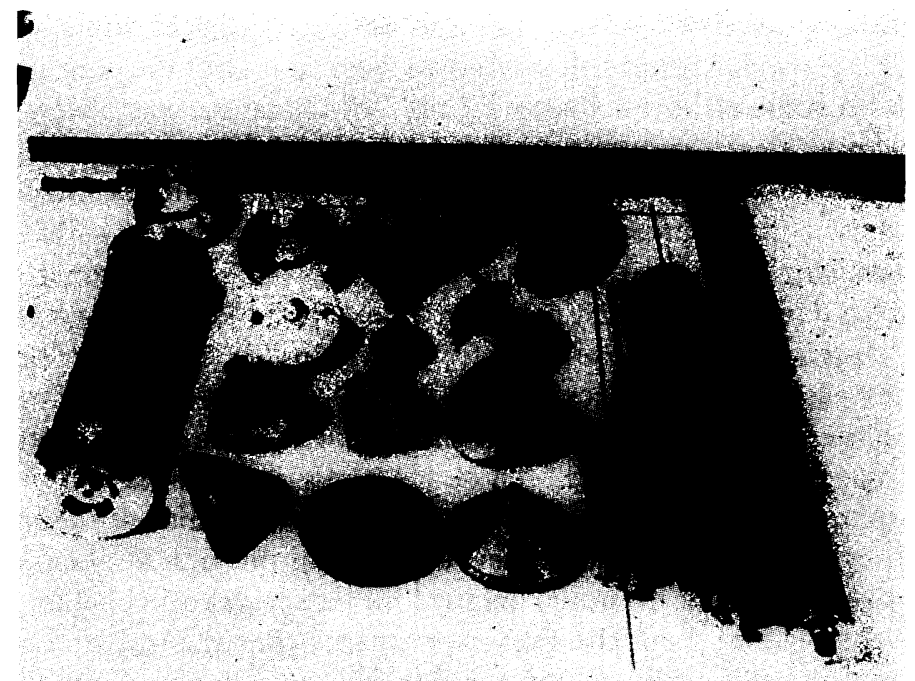

Source: J.W. Beams, 'High Rotational Speeds', Journal of Applied Physics, Vol. 8 (1937), 803. 
One of Beams' next steps was to change that part of his ultracentrifuge which the reader may now find the most typical - the air turbine. In 1937, he wrote that many laboratories did not possess air compressors of sufficient capacity for driving the turbine, and that he had therefore developed an electrical drive. ${ }^{113}$ The first electrically driven UCs were still supported by compressed air, but this only necessitated a small compressor which was easily available and cheap. Shortly thereafter, however, Beams and one of his collaborators eliminated the need for air compressors altogether by developing a magnetic form of suspension. ${ }^{114}$

From 1936 onward, Beams started to develop ultracentrifuges for a new application - isotope separation. Isotopes are atoms of the same chemical element, but with different masses. Thus, we speak of the isotope uranium-235 and the isotope uranium-238. The possibility of separating isotopes using a centrifuge had been suggested as early as 1919 , but in the absence of suitable centrifuges it was dismissed as 'not practicable'.115 With his fast vacuum centrifuges, Beams succeeded in effecting a demonstrable separation, in the first instance of chlorine isotopes. ${ }^{116}$ In $1939-40$, separation of uranium isotopes (uranium enrichment) became an important issue in view of the possible construction of nuclear weapons in the United States. Although the production of enriched uranium in the Beams centrifuges was very small, it was decided in 1940 to build a pilot plant with these centrifuges. However, in January 1944 the ultracentrifuge project for uranium enrichment was terminated, ${ }^{117}$ because it was decided to opt for another uranium enrichment technology, that of gaseous diffusion. A good ten years later, further developments in UC technology for uranium enrichment were instigated in several countries, including the Netherlands, the Federal Republic of Germany (where there had already been a small programme during and after World War II), and the USA, where Beams resumed his earlier work. ${ }^{118}$

\section{Diffusion of Ultracentrifuges}

Svedberg Ultracentrifuges

Svedberg's work was highly thought of by his colleagues. Many researchers from different countries visited Uppsala to work with ultracentrifuges. Some of them brought the substance they wanted to 
investigate, some just took part in the work that was going on. Typically there were about half a dozen foreigners per year working at Uppsala, sometimes staying for a few months, sometimes staying for one or two years, or, like Kai O. Pedersen, staying for the remainder of their career. The demand for centrifuge-time was very high, and by the end of the 1930s three oil-turbine centrifuges were running almost permanently in Svedberg's laboratory. Also the older, electrically-driven type was frequently used for sedimentation equilibrium experiments. ${ }^{119}$

Some of these foreign researchers showed great interest in obtaining an ultracentrifuge of their own. However, the difficulties of achieving this were very considerable. Construction of the ultracentrifuge required extremely skilled workmanship. Experience with this specific type of rotating system only existed in Svedberg's workshop. Svedberg did allow Eriksson to make ultracentrifuges for others, but there still was the problem of cost - about $\$ 20,000$ for the whole apparatus - a huge sum of money. Altogether, four visiting scientists succeeded in finding the money needed to buy an oil-turbine ultracentrifuge. All of these were made by Eriksson in his workshop, two of them funded through the Rockefeller Foundation, one funded through the British Royal Society, and one paid for by a private company for research in its own laboratory. ${ }^{120}$

By the end of the 1930s, Svedberg started to show some interest in more actively making his centrifuge method and apparatus known. He and Pedersen edited a book, published in 1940 in English and German, with contributions from various scientists who had been working with ultracentrifuges. ${ }^{121}$ In 1938 , they published an article in Review of Scientific Instruments about the ultracentrifuge. ${ }^{122}$ Until then, Svedberg had published mainly in (bio) chemical journals such as Journal of the American Chemical Society, Journal of Biological Chemistry, Kolloid Zeitschrift and Biochemisches Zeitschrift. In most of these articles, the emphasis was on experimental results, and the UC was described as an element in the experimental method. In the 1938 article, however, the emphasis was on the ultracentrifuge itself. In the final part of that article, Svedberg and his colleagues compared their UC with the Beams-Pickels type, and concluded that the energy efficiency of theirs was better than that of the air-driven one. ${ }^{123}$ In the early 1940s, partly on the initiative of Svedberg and Sven Brohult one of his students - a company was formed in Stockholm called LKB-Produkter. This company was to manufacture a variety of scientific instruments, one of which was the oil-turbine ultracentrifuge. 
Though in general terms the company was a great success, the oilturbine ultracentrifuge was a commercial failure. Only two or three of them were sold. ${ }^{124}$

\section{Beams' Ultracentrifuges}

By contrast, the ultracentrifuges developed in line with Beams' concepts have found wide distribution. In the mid-1930s, Johannes Bauer, working at the International Health Division Laboratories of the Rockefeller Foundation, asked Pickels to adapt the vacuumultracentrifuge for his study of the sedimentation of viruses. Pickels thereupon further developed this ultracentrifuge for Bauer's sedimentation experiments. In this apparatus, the cells in which the actual sedimentation took place, as well as the optical system, were copies of Svedberg's centrifuge. These ultracentrifuges were made in the Foundation's workshop, some also for other laboratories in the US. In 1936, Bauer and Pickels were visited by Svedberg, who was impressed by their achievements and concluded that they had indeed constructed an ultracentrifuge. Thereupon, he invited them to write a chapter about the air-driven ultracentrifuge for the book he was editing with Pedersen. ${ }^{125}$

In the mid-1930s, the then leading manufacturer of centrifuges in the world, the Sharples Company in Philadelphia, showed interest in selling ultracentrifuges. They approached Beams and Pickels for advice and, in 1936, the first Sharples-ultracentrifuge was put on the market. ${ }^{126}$ Like Svedberg's oil-turbine type this air-turbine ultracentrifuge was also a commercial failure. ${ }^{127}$

In the mid-1940s, Pickels decided that there might be a market for ultracentrifuges after all. Together with Maurice Hanefin, who had an industrial background, he decided to form a company called Spinco (Specialized Instruments Corporation). Knowing the fate of the Sharples UC, he concluded that the air-turbine drive prevented it from being widely applicable; many laboratories did not have the necessary air-compressors for driving it. As mentioned before, Beams had addressed the same problem in the late 1930s and had developed an electrical drive for his UCs. Pickels decided that such a drive might serve his purposes better than the air-turbine. Thereupon he was able to produce ultracentrifuges at a price which was approximately onethird of the price of the oil-turbine type, and it soon became a commercial success. ${ }^{128}$ In 1947 , eight oil-turbine ultracentrifuges 
were used world-wide, and just about as many air-driven ones. Ten years later, more than 300 electrically driven Spinco ultracentrifuges were spinning around the world. ${ }^{129}$

\section{Discussion and Conclusion}

I have shown that an ultracentrifuge meant something completely different for Svedberg and for Beams. For Svedberg, the stimulus to develop the ultracentrifuge was to build an instrument for colloid chemical research. This implied that the UC had to fulfil specific requirements or it might be consigned to the scrap-heap. For Beams, on the other hand, the stimulus was primarily to reach high rotational speeds with a simple driving mechanism, naive as this may sound. For him, almost anything that rotated fast was an ultracentrifuge. If we consider Svedberg's case, we find two very different UCs used for more or less the same purpose (see Figures 2 and 4). In Beams' case (see Figures 3, 6 and 7), we find the same driving mechanism in all three cases. By contrast, the rotors show considerable differences which relate to the different purposes for which they were built.

The different meanings they attributed to an ultracentrifuge caused the researchers to have very different views about which aspects of the centrifuge caused problems. Therefore, they evaluated the effects of modifications applied to their UC in different ways. To Svedberg, a modification was only an 'improvement' if it was not made at the expense of the ultimate goal of his experimental method. For example, the centrifuge capable of generating the highest gravitational field was rejected by him on grounds of its inferior resolving power. To Beams, any improvement to any aspect of the centrifuge was worth a publication. Any potential application was interesting as it might generate interesting research questions. In the end, not even the air-turbine survived Beams' quest for further improvements. As a consequence of the different attributed meanings, the developmental processes and the eventual appearance of the two ultracentrifuges differed greatly in a number of ways.

But it was not only ultracentrifuges which differed in a technological sense that meant something different to the researchers involved. Artefacts with the same technological characteristics could also take on different meanings. This demonstrates the interpretative flexibility of the ultracentrifuge. In the Beams case, there did not exist just one air-driven spinning top, but there was a means for rotating 
mirrors and a means for centrifuging substances. Each of these led to very different developments and artefacts. In the Svedberg case, in 1925, there was not just the ultracentrifuge but there was the sedimentation equilibrium machine and the sedimentation velocity machine. The first kept its original electrical drive, the second led to the development of the oil-turbine drive.

In trying to solve their problems, the two researchers had to do more then put some technological elements in the right place. In Law's vocabulary, we could say that in a process of heterogeneous engineering ${ }^{130}$ the researchers tried to influence 'social' and 'natural' factors: Svedberg turned his one time adversary of 'diffusion' into an ally. He had to convince others to give him money for his development work, and he succeeded by offering them his status of a Nobel Prize winner. Beams had to convince many others of the value of his artefacts: he did this by stressing the simplicity and flexibility of his artefacts, and by offering his assistance in helping to adapt the machine to any specific needs a potential customer might have.

One of the purposes of this paper is to show that a comparison of case studies can be helpful in answering theoretical questions. I shall not offer a complete theoretical analysis here, but on the basis of the present case study I conclude by pointing to some aspects which in my opinion should play a role in such analysis.

If we look at the final widespread application of ultracentrifuges, we may say that one of them became a success while the others became a failure. However, if we had asked colloid and protein chemists in the mid-1930s to point to the most successful UC, the answer would most probably have been the Svedberg type. Thus, the study warns us that it can be misleading to talk simply about 'success' and 'failure', and that it might be more fruitful to talk about 'growing' and 'diminishing' degrees of stabilization. Why, then, did the Beams/Pickels type stabilize whereas, in the end, the Svedberg type did not? The obvious answer, it seems, is that the latter was extremely expensive and complicated to build, whereas the former was much cheaper, less complicated, easier to operate and more widely applicable. But how did they come to possess these characteristics? Mainly because the various ultracentrifuges were developed through very different design processes. And one of the reasons that these processes differed so greatly, was that for the two researchers an ultracentrifuge meant something different. Thus, this comparative study suggests that the meaning the various actors attribute to an 
artefact should play an important role in theoretical explanations about the development of technological artefacts.

The calling-in of external know-how strongly influenced the further development of Svedberg's UC. By so doing, Svedberg introduced a particular company 'tradition' in the construction of turbines and rotating systems. This tradition can also be traced in the centrifuges built for him. It led to a horizontal axis of rotation, bearings which produced considerable heat and a hydrogen atmosphere at reduced pressure to prevent the heat from disturbing the sedimentation process. Beams, on the other hand, belonged to an entirely different technological tradition, where all the work was done in his own workshop and seemed to bear the motto 'the simpler the better'. The air-turbine originally had a vertical axis of rotation and was supported by an air cushion. When Beams wanted to put a heavy rotor on it, he used a flexible shaft to connect it with the turbine. This allowed the rotor to seek its own axis of rotation, which automatically compensated for imbalances in its weight. Therefore, Beams was not faced with the problem of the heating of the bearings at all. Thus, a certain tradition for dealing with technological problems will condition the eventual design of an artefact, and, consequently, is one of the important factors in its developmental process. This conclusion lends further support to the analyses of Constant, Dosi, Hughes and Bijker. ${ }^{131}$ The kind of tradition I have described forms one element of Bijker's concept of a 'technological frame'. ${ }^{132}$

- NOTES

I am grateful to Wiebe Bijker, Peter Boskma and two anonymous referees for stimulating comments on earlier drafts of this paper. I would like to thank Yolande Samwel for translating the paper. This paper is based partly on interviews with people who have been engaged in, or are familiar with, the development of ultracentrifuges. I want to thank the Stichting Hogeschoolfonds Twente and the Netherlands Organization for the Advancement of Pure Research (ZWO) for financial support which made it possible to carry out these interviews.

1. T.P. Hughes, Networks of Power: Electrification in Western Society (London \& Baltimore, Md: The Johns Hopkins University Press, 1983), and Hughes, 'The Seamless Web: Technology, Science, Etcetera, Etcetera', Social Studies of Science, Vol. 16 (1986), 281-92. See also Donald Mackenzie, 'Missile Accuracy: An Arms 
Control Opportunity', Bulletin of the Atomic Scientists, Vol. 42, No. 6 (June/July 1986), 11-16, and Mackenzie, 'The Missile Accuracy System', paper read to the International Congress of the History of Science, University of California, Berkeley, 31 July-8 August 1985.

2. J. Law, 'Technology and Heterogeneous Engineering: The Case of the Portuguese Expansion', in W.E. Bijker, T.P. Hughes and T.J. Pinch (eds), The Social Construction of Technological Systems, New Directions in the Sociology and History of Technology (Cambridge, Mass.: MIT Press, 1987, forthcoming). See also M. Callon, J. Law and A. Rip (eds), Mapping the Dynamics of Science and Technology (London: MacMillan, 1986 forthcoming); B. Latour, Science in Action: How to Follow Scientists and Engineers through Society (Milton Keynes, Bucks.: The Open University Press, 1986, forthcoming); M. Callon, 'The State and Technical Innovation: A Case Study of the Electrical Vehicle in France', Research Policy, Vol. 9 (1980), 358-76, and Callon, 'Society in the Making: The Study of Technology as a Tool for Sociological Analysis', in Bijker, Hughes \& Pinch (eds), op. cit.

3. Law, op, cit. note 2 .

4. T.J. Pinch and W.E. Bijker, 'The Social Construction of Facts and Artefacts: or How the Sociology of Science and the Sociology of Technology might Benefit Each Other', Social Studies of Science, Vol. 14 (1984), 399-441.

5. R. Laudan (ed.), The Nature of Technological Knowledge: Are Models of Scientific Change Relevant? (Dordrecht: Reidel, 1984); D. MacKenzie and J. Wajcman (eds), The Social Shaping of Technology (Milton Keynes, Bucks.: The Open University Press, 1985).

6. Pinch \& Bijker, op. cit. note 4, 421-24.

7. J.M. Staudenmaier, SJ, Technology's Storytellers: Reweaving the Human Fabric (Cambridge, Mass.: MIT Press, 1985).

8. J. Law, 'International Workshop on New Developments in the Social Studies of Technology', 4S Review, Vol. 2 (Winter 1984), 9-13, esp. 13.

9. Bijker, Hughes \& Pinch (eds), op. cit. note 2. This volume is based on the International Workshop on 'New Developments in the Social Studies of Technology', 4-7 July 1984, Enschede, The Netherlands.

10. Pinch \& Bijker, op. cit. note 4, 414-15.

11. Ibid., 422.

12. Ibid., 421-24.

13. Ibid., 415-16.

14. Ibid., 411.

15. Ibid., 416.

16. W.E. Bijker, 'The Social Construction of Bakelite - Towards a Theory of Invention', in Bijker, Hughes \& Pinch (eds), op. cit. note 2.

17. In the 1950s and 1960s, a new type of ultracentrifuge was developed in a number of countries for the purpose of uranium enrichment. The development of this ultracentrifuge will not be described here since it has only been studied briefly. Carrying out that case study will be the next step in my research project.

18. S. Claesson and K.O. Pedersen, 'The Svedberg, 1884-1971', Biographical Memoirs of Fellows of the Royal Society, Vol. 18 (London, 1972), 595-627, esp. 595.

19. T. Svedberg, Colloid Chemistry (New York: The Chemical Catalog Company, 1924), 14.

20. T. Graham, 'Liquid Diffusion Applied to Analysis', Philosophical Transactions of the Royal Society of London, Vol. 151 (1861), 183. 
21. E.L. Hess, 'Origins of Molecular Biology', Science, Vol. 168 (8 May 1970), 664-69, esp. 666.

22. M. Kerker,' The Svedberg and Molecular Reality', Isis, Vol. 67 (1976), 190-216, esp. 193.

23. H. Siedentopf and R. Zsigmondy, 'Uber die Sichtbarmachung und Grössenbestimmung ultramikroskopischer Teilchen, mit besonderer Anwendung auf Goldrubingläsern', Annalen der Physik, Bd. 10 (1903), 1-39.

24. J.T. Edsall, 'Proteins as Macromolecules: an Essay on the Development of the Macromolecule Concept and Some of Its Vicissitudes', Archives on Biochemistry and Biophysics, Supplement 1 (1962), 12-20, esp. 17.

25. T. Svedberg, 'Studien zur Lehre von den Kolloiden Lösungen', Nova Acta Regiae Societatis Scientiarum Upsaliensis, Vol. 2 (1907), 1-160.

26. Claesson \& Pedersen, op. cit. note 18, 617-19.

27. T. Svedberg, Die Methoden zur Herstellung Kolloider Lösungen Anorganischer Stoffe (Dresden: Theodor Steinkopff, 1909); translated as The Formation of Colloids (London: J. \& A. Churchill, 1921).

28. Claesson \& Pedersen, op. cit. note 18, 598.

29. Ibid., 599.

30. T. Svedberg und K. Estrup, 'Ueber die Bestimmung der Häufigkeitsverteilung der Teilchengrössen in einem dispersen System', Kolloid Zeitschrift, Bd. 9 (1911), 259-61, esp. 259.

31. Ibid., 260.

32. S. Odén, 'On the Size of the Particles in Deep-Sea Deposits', Proceedings of the Royal Society of Edinburgh, Vol. 36 (Sess. 1915-16), 219-36.

33. T. Svedberg and H. Rinde, 'The Determination of the Distribution of Size of Particles in Disperse Systems', Journal of the American Chemical Society, Vol. 45 (1923), 943-54.

34. Physicists make no distinction in principle between the forces generated by gravity and the forces generated in centrifuges. Both forces give particles an acceleration which depends upon the mass of the particle. For this reason physicists often express the forces generated in a centrifuge in terms of the strength of the earth's gravitational field. A centrifugal force of $1000 \mathrm{~g}$ means that we are dealing with forces of one thousand times gravity ( $\mathrm{g}$ being the acceleration of the earth's gravitational field).

35. Svedberg \& Rinde, op. cit. note 33, 949.

36. Ibid., 950-53.

37. Claesson \& Pedersen, op. cit. note $18,600$.

38. K.O. Pedersen, 'The Development of Svedberg's Ultracentrifuge', in M.G. Lewis and G.H. Weiss (eds), Fifty Years of the Ultracentrifuge (Amsterdam: North-Holland Publishing Company, 1976), 3-18, esp. 4.

39. Ibid., 5.

40. T. Svedberg and H. Rinde, 'The Ultra-Centrifuge, a New Instrument for the Determination of Size and Distribution of Size of Particle in Amicroscopic Colloids', Journal of the American Chemical Society, Vol. 46 (1924), 2677-93, esp. 2677-78 (italics in original).

41. See note 34 .

42. Obviously, I have been guided by the SCOT method in giving the previous account: concentrating on the meanings attributed by Svedberg, as a member of the 
social group of colloid chemists, to the artefact centrifuge and subsequently focusing on the problems he perceived, A very similar account would have resulted if $I$ had used Tom Hughes' concepts of the 'reverse salient' (here: the disturbing of the sedimentation of colloidal substances) and 'critical problems' (here: cell-shape, heating, vibration).

43. Svedberg \& Rinde, op. cit. note 40, 2687-92.

44. T. Svedberg, 'Zentrifugierung, Diffusion und Sedimentationsgleichgewicht von Kolloiden und hochmolekularen Stoffen', Kolloid Zeitschrift-Zsigmondi Festschrift, Bd. 36 (1925), 53-64, esp. 54.

45. Svedberg \& Rinde, op. cit. note 40, 2682.

46. Ibid., 2682-83.

47. Ibid., 2684.

48. Svedberg, op. cit. note $44,59-60$.

49. E. Henriot et E. Huguenard, 'Sur la réalisation de très grandes vitesses de rotation', Comptes Rendues Hebdomaires des Séances del l' Académie des Sciences, Tome 180 (1925), 1389-92.

50. E. Henriot et E. Huguenard, 'Les Grandes Vitesses Angulaires Obtenus par les Rotors sans Axe Solide', Le Journal de Physique et le Radium, Série 6, Tome 8 (1927), 433-43.

51. W. Gordy, 'Jesse Wakefield Beams', in Biographical Memoirs of the National Academy of Sciences of the USA, Vol. 54 (Washington, DC: National Academy Press, 1983), 3-49, esp. 5-6.

52. Ibid., 7-8.

53. E.O. Lawrence, J.W. Beams and W.D. Garman, 'An Improved Arrangement for Obtaining High Speeds of Rotation', Physical Review, Vol. 31 (1928), 1112.

54. Gordy, op. cit. note 51, 10.

55. T.J. Pinch, 'Theoreticians and the Production of Experimental Anomaly: The Case of Solar Neutrinos', in K.D. Knorr and R. Whitley (eds), The Social Process of Scientific Investigation, Sociology of the Sciences Yearbook, Vol. 4 (Dordrecht/Boston/ Lancaster: D. Reidel, 1980), 77-106, esp. 78.

56. F.L. Brown, A Brief History of the Physics Department of the University of Virginia, 1922-1961 (Charlottesville, Va.: University of Virginia, 1967, unpublished), Chapter 5, 2.

57. J.W. Beams, 'Spectral Phenomena in Spark Discharges', Physical Review, Vol. 35 (1930), 24-33.

58. J.W. Beams, 'The Propagation of Luminosity in Discharge Tubes', Physical Review, Vol. 36 (1930), 997-1001.

59. J.W. Beams, 'An Apparatus for Obtaining High Speeds of Rotation', Review of Scientific Instruments, Vol. 1 (1930), 667-71.

60. J.W. Beams and A.J. Weed, 'A Simple Ultra-Centrifuge', Science, Vol. 74 (10 July 1931), 44-46, esp. 44.

61. Ibid., 45.

62. Ibid., 44-45.

63. F.N. Schulz, Die Grösse des Eiweissmoleküls (Jena: Verlag von Gustav Fischer, 1903).

64. Ibid., 101. Translation: 'On the whole the picture is not heartening'.

65. Edsall, op. cit. note 24, 14.

66. P.J. Flory, Principles of Polymer Chemistry (Ithaca, NY: Cornell University Press, 1953), 3-28.

67. Edsall, op. cit. note 24, 15-16. 
68. Ibid., 17.

69. Hess, op. cit. note 21, 666, and Edsall, op. cit. note 24, 17.

70. Edsall, op. cit. note 24, 18.

71. Claesson \& Pedersen, op. cit. note 18, 601.

72. K.O. Pedersen, 'The Svedberg and Arne Tiselius: The Early Development of Modern Protein Chemistry at Uppsala', in A. Neuberger, L.L.M. van Deenen and G. Semenza (eds), Comprehensive Biochemistry, Vol. 35: 'Selected Topics in the History of Biochemistry; Personal Recollections: I' (Amsterdam: Elsevier Science Publishers, 1983), 233-81, esp. 240-41.

73. Ibid., 241.

74. Ibid.

75. T. Svedberg, 'Ultrazentrifugale Dispersitätsbestimmungen an Eiweisslösungen', Kolloid Zeitschrift, Bd. 51 (1930), 10-24, esp. 10 (translated from German by the author). Original German text: 'Als der Verf. nach einigen mit J.B. Nichols ... und H. Rinde . . . ausgeführten Messungsreihen an anorganischen Kolloiden, spez. an Goldhydrosolen, an die Aufgabe ging die Dispersität der Proteine zu studieren, war er in der festen Ueberzeugung, dass die letzteren ebenso wie die Goldhydrosole sich als polydispers heraustellen würden. Die Aufgabe, die er sich stellte, war also die Bestimmung der Teilchenverteilungskurven der Eiweisskörper unter verschiedenen Versuchsbedingungen.'

76. T. Svedberg and R. Fåhraeus, 'A New Method for the Determination of the Molecular Weight of the Proteins', Journal of the American Chemical Society, Vol. 48 (1926), 430-38, esp. 430.

77. Ibid., 436.

78. Pedersen, op. cit. note 38,6 .

79. Pedersen, op. cit. note 72, 242.

80. T. Svedberg, 'The Ultracentrifuge and Its Field of Research', Industrial and Engineering Chemistry, Analytical Edition, Vol. 10 (1938), 113-27, esp. 114.

81. Pedersen, op. cit. note 72, 242.

82. Claesson \& Pedersen, op. cit. note 18, 603.

83. Pedersen, op. cit. note 38,7 .

84. Nobel Lectures Physics; 1901-1921 (Amsterdam: Elsevier Publishing Company, 1967), 479.

85. Ibid.

86. Nobel Lectures Chemistry; 1922-1940 (Amsterdam: Elsevier Publishing Company, 1966), 63-66.

87. Nobel Lectures Physics; 1922-1940 (Amsterdam: Elsevier Publishing Company, 1967), 135-37.

88. Op. cit. note $86,41-44$.

89. Ibid., 63.

90. T. Svedberg, Diary (Uppsala, manuscript department of the university library; unpublished).

91. Op. cit. note $86,67-83$.

92. Svedberg, op. cit. note 90.

93. O. Lamm, 'Zur Bestimmung von Konzentrationsgradienten mittels gekrümter Lichtstrahlen', Zeitschrift für Physikalische Chemie, Abt. A, Bd. 138 (1928), 313-31.

94. Pedersen, op. cit. note $38,8-16$.

95. Pedersen, op. cit. note 72, 243.

96. Prof. Kai O. Pedersen; private communication. 
97. Pedersen, op. cit. note $38,13$.

98. Ibid., 15.

99. E.G. Pickels, The Air-Driven Ultra-Centrifuge (Charlottesville, Va.: University of Virginia, 1935, unpublished dissertation).

100. J.W. Beams, A.J. Weed and E.G. Pickels, 'The Ultracentrifuge', Science, Vol. 78 (13 October 1933), 338-40, esp. 339.

101. Ibid., 339-40.

102. Ibid., 340.

103. E.N. Harvey and A.L. Loomis, 'A Microscope Centrifuge', Science, Vol. 72(11 July 1930), 42-44.

104. E.M. Harvey, 'The Microscope-Centrifuge and Some of its Applications', Journal of the Franklin Institute, Vol. 214 (1932), 1-23, and Harvey, 'The CentrifugeMicroscope for Super-Centrifugal Forces', Science, Vol. 75 (4 March 1932), 267-68.

105. H.W. Beams and R.L. King, 'Effect of Ultra-Centrifuging on the Cells of the Root-Tip of the Bean', Nature, Vol. 135 (9 February 1935), 232; Beams and King, 'Survival of Ascaris Eggs after Centrifuging', Science, Vol. 84 (7 August 1936), 138; and Beams, 'The Air Turbine Ultracentrifuge, together with some Results upon Ultracentrifuging the Eggs of Fucus Serratus', Journal of the Marine Biological Association, Vol. 21 (1937), 571-88.

106. J.W. Beams and E.G. Pickels, 'The Production of High Rotational Speeds', Review of Scientific Instruments, Vol. 6 (1935), 299-308, esp. 302.

107. Ibid.

108. E.G. Pickels and J.W. Beams, 'High Rotational Speeds in Vacuum', Physical Review, Vol. 47 (1935), 336-37.

109. E.G. Pickels and J.W. Beams, 'High Rotational Speeds in Vacuo', Science, Vol. 81 (5 April 1935), 342-43.

110. Beams \& Pickels, op. cit. note 106.

111. Ibid., 304.

112. Ibid., 308.

113. J.W. Beams and L.B. Snoddy, 'The Electrically Driven Ultracentrifuge', Science, Vol. 85 (12 February 1937), 185-86.

114. J.W. Beams, 'High Speed Centrifuging', Reviews of Modern Physics, Vol. 10 (1938), 245-63, esp. 253.

115. J.W. Beams and F.B. Haynes, 'The Separation of Isotopes by Centrifuging', Physical Review, Vol. 50 (1936), 491-92, esp. 491.

116. J.W. Beams and L.B. Snoddy, 'The Separation of Mixtures by Centrifuging', Journal of Chemical Physics, Vol. 5 (1937), 993-94.

117. J.W. Beams, Early History of the Gas Centrifuge Work in the USA (Charlottesville, Va.: University of Virginia, 1975, unpublished), 15-26.

118. Ibid., 29-39. See also D.R. Olander, 'The Gas Centrifuge', Scientific American, Vol. 239 (August 1978), 27-33.

119. Prof. Kai O. Pedersen; private communication.

120. Pedersen, op. cit. note 72, 268.

121. T. Svedberg und K.O. Pedersen (eds), Die Ultrazentrifuge (Leipzig: Theodor Steinkopff, 1940). Also published in an English edition as The Ultracentrifuge (Oxford: The Oxford University Press, 1940).

122. G. Boestad, K.O. Pedersen and T. Svedberg, 'Design and Operation of the Oil-Turbine Ultracentrifuge', Review of Scientific Instruments, Vol. 9 (1938), 346-53. 
123. Ibid., 353.

124. Prof. Sven Brohult and Harry Brynielsson; private communication. $\mathrm{Mr}$ Brynielsson was the first managing director of LKB-Produkter.

125. Dr Edward G. Pickels; private communication. See also J. Bauer and E.G. Pickels, 'A High Speed Vacuum Centrifuge Suitable for the Study of Filterable Viruses', Journal of Experimental Medicine, Vol. 64 (1936), 503-28, and J. Biscoe, Pickels and R.W.G. Wyckoff, 'An Airdriven Ultracentrifuge for Molecular Sedimentation', Journal of Experimental Medicine, Vol. 64 (1936), 39-45.

126. W.L. Marston, 'Centrifugals', Industrial and Engineering Chemistry, Industrial Edition, Vol. 28, No. 11 (1936), editorial supplement, 55-58, esp. 58.

127. Thomas D. Sharples; private communication.

128. Dr Edward G. Pickels; private communication.

129. H.K. Schachman, Ultracentrifugation in Biochemistry (New York: Academic Press, 1959), 1.

130. Law, op. cit. note 2.

131. E.W. Constant, II, The Origins of the Turbojet Revolution (Baltimore, Md: The Johns Hopkins University Press, 1980); G. Dosi, 'Technological Paradigms and Technological Trajectories - a Suggested Interpretation of the Determinarits and Directions of Technical Change', Research Policy, Vol. 11 (1982), 147-62; Hughes, Networks of Power, op. cit. note 1; and W.E. Bijker, 'Collectifs technologiques et styles technologiques. Eléments pour un modèle explicatif de la construction sociale des artefacts techniques', in J.H. Jacot (coörd.), Travailleur Collectif et Relations ScienceProduction (Paris: Editions du C.N.R.S., 1984), 113-20.

132. Bijker, op. cit. note 16 .

Boelie Elzen graduated in electrotechnical engineering at Twente University in 1979, having studied the interrelations of technological and societal developments with a special emphasis on problems of the arms race. He has since been working for a doctorate at the Centre for Studies on Problems of Science and Society at Twente, his thesis project being on 'Determinative Factors in the Development of Ultracentrifuges'. He has already investigated ultracentrifuges used for uranium enrichment, from the perspective of their potential implications for the arms race: see, for example, Allan S. Krass, Peter Boskma, Boelie Elzen and Wim A. Smit, Uranium Enrichment and Nuclear Weapon Proliferation (London: Taylor \& Francis, for the Stockholm International Peace Research Institute, 1983). Author's address: 'de Boerderij', Twente University, PO Box 217, 7500 AE Enschede, The Netherlands. 